\title{
Those most at risk of involvement in knife crime are the least likely to have any interactions with a GP
}

\author{
Nicholas Pound senior lecturer in psychology \\ Department of Life Sciences, Brunel University London, UB8 3PH, UK
}

The call for knife crime to be tackled as a "public health matter" is welcome-but in opposing part of the motion, Gillian Beck raises an important point. It would be a mistake if this approach were to place too much emphasis on interventions by GPs aimed at primary prevention. This is not only because GPs are already overburdened, however, but also because the people most at risk of involvement in knife crime, either as victims or perpetrators, are the least likely to have any interactions with a GP.

In the UK, the majority of penetrating trauma cases involve young males. ${ }^{2}$ Olding et al reported, for example, that at a London trauma centre from August 2016 to July 2017 the majority of patients with penetrating trauma from interpersonal violence were male (88\%), and under $30(69 \%){ }^{3}$ In primary care, however, the lowest clinician consultation rates are seen for males in the 10-14, 15-19, and 20-24 year age bands. ${ }^{4}$ For victims of knife crime-including perpetrators who are injured-treatment by ambulance service and emergency department staff will often be the first interaction with a clinician they have had for many years. Consequently, interactions with clinicians are most plausible as a route for interventions aimed at secondary, rather than primary, prevention—such as reducing the likelihood of future involvement in knife crime for people who have already sustained an injury.

Competing interests: None declared.

Hurley R. BMA calls for knife crime to be tackled as a public health concern. BMJ 2019;365:14424. 10.1136/bmj.14424 31243016

2 Whittaker G, Norton J, Densley J, Bew D. Epidemiology of penetrating injuries in the United Kingdom: A systematic review. Int J Surg 2017;41:65-9. 10.1016/j.ijsu.2017.03.051 28343028

3 Olding J, Olding C, Bew D, Fan K. Penetrating head \& neck trauma - Epidemiology and injury characteristics in terror-related violence, interpersonal violence and deliberate self-harm at a level 1 trauma centre. Surgeon 2019;17:133-8. 10.1016/j.surge.2019.01.00130808587

4 Hippisley-Cox J, Vinogradova Y. Trends in consultation rates in general practice 1995 to

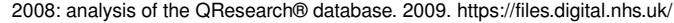
publicationimport/pub01xxx/pub01077/tren-cons-rate-gene-prac-95-09-95-08-rep.pdf.

Published by the BMJ Publishing Group Limited. For permission to use (where not already granted under a licence) please go to http://group.bmj.com/group/rights-licensing/ permissions 